


\title{
BOUNDING ESTIMATE OF DWPF MERCURY EMISSIONS (U)
}

by

R. A. Jacobs

Westinghouse Savannah River Company

Savannah River Site

Aiken, South Carolina 29808

\section{DISCLAIMER}

\begin{abstract}
This report was prepared as an account of work sponsored by an agency of the United States Government. Neither the United States Government nor any agency thereof, nor any of their employees, makes any warranty, express or implied, or assumes any legal liability or responsibility for the accuracy, completeness, or usefulness of any information, apparatus, product, or process disclosed, or represents that its use would not infringe privately owned rights. Reference herein to any specific commercial product, process, or service by trade name, trademark, manufacturer, or otherwise does not necessarily constitute or imply its endorsement, recommendation, or favoring by the United States Government or any agency thereof. The views and opinions of authors expressed herein do not necessarily state or reflect those of the United States Government or any agency thereof.
\end{abstract}

DOE Contract No. DE-AC09-89SR18035

This paper was prepared in connection with work done under the above contract number with the U.S.

Department of Energy. By acceptance of this paper, the publisher and/or recipient acknowledges the U.S. Government's right to retain a nonexclusive, royalty-free license in and to any copyright covering this paper, along with the right to reproduce and to authorize others to reproduce all or part of the copyrighted paper. 


\section{DISCLAIMER}

This report was prepared as an account of work sponsored by an agency of the United States Government. Neither the United States Government nor any dgency thereof, nor any of their employees, makes any warranty, express or implied, or assumes any legal liability or responsibility for the accuracy, completeness, or usefulness of any information, apparatus, product, or process disclosed, or represents that its use would not infringe privately owned rights. Reference herein to any specific commercial product, process, or service by trade name, trademark, manufacturer, or otherwise does not necessarily constitute or imply its endorsement, recommendation, or favoring by the United States Government or any agency thereof. The views and opinions of authors expressed herein do not necessarily state or reflect those of the United States Government or any agency thereof.

This report has been reproduced directly from the best available copy.

Available to DOE and DOE contractors from the Office of Scientific and Technical Information, P. O. Box 62, Oak Ridge. TN 37831; prices available from (615) 576-8401.

Available to the public from the National Technical Information Service, U. S. Deparment of Commerce, 5285 Port Royal Rd., Springfield, VA 22161 
Westinghouse Savannah River Company
WSRC-TR-92-1205TL

Revision 1

Keywords: UWPF, $\mathrm{Hg}$ emissions

Relention period: Permanent

cc: $\quad$ D. T. Bignell, 719-4A-

J. F. Ortaldo, 704-S

K. Z. Wolf, 704-15S-

- L. F. Landon, 704-T

-D. A. Crowley, 704-1T

D. P. Lambert, 704-1T

-J. R. Zamecnik, 704-1T

R. A. Jacobs, 704-T-

SRTC Records (4)

October 28, 1993

\section{B. AMERINE, MANAGER/DEFENSE WASTE PROCESS FACILITY WESTINGHOUSE SAVANNAH RIVER COMPANY}

ATTENTION: W. D. KImbalI, 704-S (5)

\section{BOUNDING ESTIMATE OF DWPF MERCURY SMISSIONS (U)}

H2 flammability control and elevated Formic Acid Vent Condenser exit temperatures due to NOx reactions have lead to changes in Chemical Process Cell (CPC) operating conditions.

Accordingly, bounding (maximum) mercury emissions estimates have been previously updated for the Late Wash/formic acid' process based upon the new operating requirements, IDMS (Integrated DWPF Melier System) experience, and development of an NOx/FAVC model which predicts FAVC exit temperatures. The previous estimates (Revision 0 of the attached document) have been revised to reflect our standard basis of $100 \%$ attainment for bounding emissions estimates and also to reflect the Batch 1 CPC cycle time of 100 hours. Using very conservative assumiptions and maximum purge rates, the maximum calculated $\mathrm{Hg}$ emissions are approximately $130 \mathrm{lbs} / \mathrm{yr}$ with a peak rate of $0.035 \mathrm{lbs} / \mathrm{hr}$. A range of 100 to $120 \mathrm{lbs} / \mathrm{yr}$ is conservatively predicted for other operating conditions. These estimates are approximately the same as previously transmitted. DWPF permitted $\mathrm{Hg}$ emissions are $175 \mathrm{lbs} / \mathrm{yr}(0.02 \mathrm{lbs} / \mathrm{hr}$ annual average).

Any questions about the report should be directed to R. A. Jacobs - extension 5-6431.

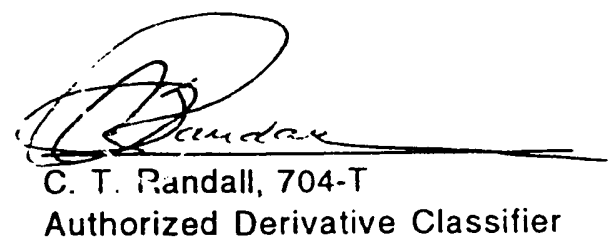

$$
\text { Ewbloetzakute }
$$

\section{AUTHENTICATED:}
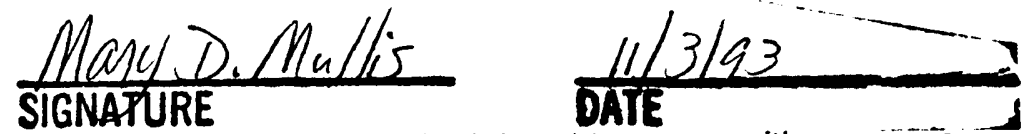

'Insufficient data exist to revise these calculations for the Late Wash/nitric acid process with ammonia scrubbers. However, emissions for LW/nitric acid are expected to be somewhat lower because of NOx scrubbing by the ammonia scrubbers which will reduce or eliminate the FAVC temperature excursions. 


\title{
INTER-OFFICE MEMORANDUM
}

\author{
WSRC-RP-92-1205 \\ Revision 1 \\ Keywords: DWPF, $\mathrm{Hg}$ emissions \\ Retention period: Permanent \\ cc: D. A. Crowley, 704-1T \\ L. F. Landon, 704-T \\ D. P. Lambert, 704-1T \\ J. R. Zamecnik, 704-1T \\ SRTC Records (4)
}

October 28, 1993

TO: $\quad$ E. W. HOLTZSCHEITER, 773-A

FROM:

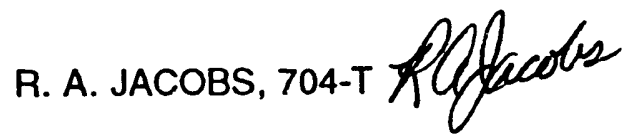

BOUNDING ESTIMATE OF DWPF MERCURY EMISSIONS (U)

\section{Summary and Conclusions}

Purges required for $\mathrm{H}_{2}$ flammability control and verification of elevated Formic Acid Vent Condenser (FAVC) exit temperatures due to $\mathrm{NO}_{x}$ reactions have lead to significant changes in Chemical Process Cell (CPC) operating conditions. Accordingly, mercury emissions estimates have been updated based upon the new operating requirements, IDMS (Integrated DWPF Melter System) experience, and development of an NOx/FAVC model which predicts FAVC exit temperatures. ${ }^{1}$ Using very conservative assumptions and maximum purge rates, the maximum calculated $\mathrm{Hg}$ emissions is approximately $130 \mathrm{lbs} / \mathrm{yr}$. A range of 100 to 120 $\mathrm{lbs} / \mathrm{yr}$ is conservatively predicted for other operating conditions. The peak emission rate calculated is $0.027 \mathrm{lbs} / \mathrm{hr}$. The estimated DWPF $\mathrm{Hg}$ emissions for the construction permit are $175 \mathrm{lbs} / \mathrm{yr}\left(0.02 \mathrm{lbs} / \mathrm{hr}\right.$ annual average). ${ }^{2}$

\section{Discussion}

\section{Background}

Two factors which have substantial impact on predicted $\mathrm{Hg}$ emissions are the air flows in the CPC and the exit temperature of the FAVC. The discovery in the IDMS of $\mathrm{H} 2$ generation by noble metal catalyzed formic acid decomposition and the resultant required dilution air flow has increased the expected instantaneous CPC air flow by as much as a factor of four. ${ }^{3}$ In

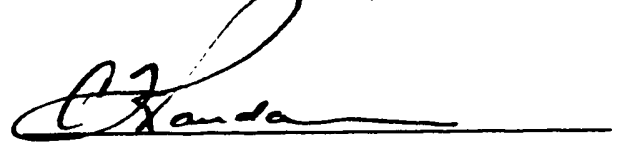

C. T. Randall, 704-T Authorized Derivative Classifier

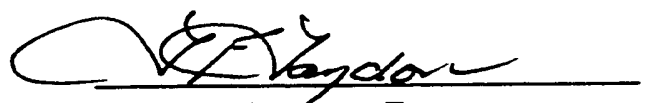

L. F. Landon, 704-T

Peer Reviewer 
addition, IDMS has experienced higher than design $\left(10^{\circ} \mathrm{C}\right) \mathrm{FAVC}$ exit temperatures during certain portions of the operating cycle. These temperatures were subsequently attributed to the exothermic reaction of $\mathrm{NO}$ to $\mathrm{NO}_{2}$. Moreover, evaluation of the DWPF FAVC indicated it was undersized and unless modified or replaced, routine exit temperatures would be in excess of design.

Subsequent experimentation, both small scale and large scale, has verified $\mathrm{H} 2$ generation rates and required maximum operating air dilution flows. ${ }^{3}$ Also, a combination kinetic, empirical model has been developed to predict the CPC offgas temperature exiting the FAVC which takes into account the residence time in the riser/mist eliminator. ${ }^{1}$

There are two other sources of $\mathrm{Hg}$ emissions in DWPF. The melter offgas flow from the Offgas Condenser (OGC) is significant and contributes approximately half of the total $\mathrm{Hg}$ emissions.

The other source is the Salt Cell Vent Condenser (SCVC) which also contains small amounts of $\mathrm{Hg}$; estimated to be a maximum of two $\mathrm{lbs} / \mathrm{yr}$.

\section{Calculations}

\section{Assumptions and Notes}

\section{General}

- All streams (FAVC, OGC, and SCVC) are assumed to be saturated at all times with elemental $\mathrm{Hg}$ at the condenser exit temperature. This should be an extremely conservative assumption for the FAVC since $\mathrm{Hg}$ is steam stripped from the SRAT (Sludge Receipt and Adjustment Tank) and SME (Slurry Mix Evaporator) for only about one-third of the cycle time and since it is likely that $\mathrm{Hg}$ is not evolved when the melter is idling. This conservative assumption allows for the possibility of significant $\mathrm{Hg}$ aerosol collection on the FAVC and OGC high efficiency mist eliminators (HEMEs) which then evaporates at a later time when $\mathrm{Hg}$ is not being evolved.

- The streams are also assumed to be saturated with water vapor at all times.

- $\mathrm{Hg}$ vapor pressure is calculated by the equation

$$
\log p(\mathrm{~mm} \mathrm{Hg})=8.0866-\frac{3227}{T\left({ }^{\circ} \mathrm{K}\right)}
$$

derived from $\mathrm{Hg}$ vapor pressure data for the a temperature range of $0-100{ }^{\circ} \mathrm{C} .4$

- Water vapor pressure is calculated by the equation 5

$$
\log \mathrm{p}(\mathrm{mm} \mathrm{Hg})=8.07131-\frac{1730.63}{233.426+\mathrm{T}\left({ }^{\circ} \mathrm{C}\right)}
$$

- Attainment is $100 \%$ or $8760 \mathrm{hr} / \mathrm{yr}$

- $\mathrm{CPC}$ operating pressure is $740 \mathrm{~mm} \mathrm{Hg}$ abs. 
E.W. HOLTZSCHEITER

Melter Offgas

- Offgas flows per CPES material balance 6

- Offgas emissions are

\title{
Annual OGC Hg Emissions
}

\author{
Air flows \\ OGFC Cooling Air \\ OGFC Dilution Air \\ 425 \\ Backup Film Cooler Air \\ TV Lens Purge \\ Melter Air Inleakage \\ 100 \\ Seal Pot Purge \\ 20 \\ Bubbler Purge \\ 15 \\ Can Bellows Inleakage \\ 40 \\ Pour Spout Siphon Break \\ Melter Control Air \\ Control Air to Ejector \\ OGCT Air Inleakage \\ Emissions @ $10^{\circ} \mathrm{C}$ \\ Total OGC air flow - pph \\ 1720 \\ Total OGC flow - lbmol/yr \\ 526070 \\ Total OGC Hg emissions - Ibs/yr 69.9
}

\section{SCVC Offgas}

- Maximum $\mathrm{Hg}$ emissions can be quickly estimated by ratioing to the maximum allowable benzene emissions which are 36 tons/yr. At $10^{\circ} \mathrm{C}$, the vapor pressures of benzene and $\mathrm{Hg}$ are $45.4 \mathrm{~mm} \mathrm{Hg}$ and $0.00049 \mathrm{~mm} \mathrm{Hg}$, respectively. The maximum $\mathrm{Hg}$ emissions would be

$$
\frac{72000 \mathrm{lbs} \text { benz/yr }}{78 \mathrm{lbs} \text { benz/lbmol benz }} * \frac{0.00049 \mathrm{~mm} \mathrm{Hg}}{45.4 \mathrm{~mm} \mathrm{Hg}} * 200.6 \frac{\mathrm{lbs} \mathrm{Hg}}{\mathrm{lbmol} \mathrm{Hg}}=2.0 \mathrm{lbs} / \mathrm{yr}
$$

\section{CPC Offgas}

- FAVC exit temperature estimates

- nitric acid SRAT flowsheet in use

- maximum $\mathrm{NO}_{x}$ evolution equals maximum for formic acid flowsheet at $0.4 \mathrm{gpm}$ formic acid (insufficient IDMS runs to develop correlation)

- high nitrite sludge $(0.25-0.35 \mathrm{M})$ 
- SRAT condenser exit temperature at $50^{\circ} \mathrm{C}$ (design)

- FAVC exit temperature at $10^{\circ} \mathrm{C}$ except during $\mathrm{NO}_{x}$ evolution

- negligible $\mathrm{CO}_{2}$ evolution during peak $\mathrm{NO}_{x}$ evolution

- $250 \mathrm{lbs} / \mathrm{hr}$ total air inleakage total for other vessels which vent to FAVC (MFT, PRBT, SMECT, and MWWT)

- In cases 1-3, SRAT condenser to FAVC line size is $6^{\prime \prime} ; 3^{\prime \prime}$ in cases 4 and 5

- FAVC exit temperature estimated by model documented in Reference 1

- Duration of $\mathrm{NO}_{x}$ peak is 2 hours/100 hour batch cycle; NOx is zero at all other times

- Offgas flow rates are peak values at maximum $\mathrm{NO}_{\mathbf{x}}$ "olution

- Peak $\mathrm{CO}_{2}$ evolution is $300 \mathrm{lbs} / \mathrm{hr}$; duration of two hours/cycle; zero at all other times

- SRAT and SME air purges are on $100 \%$ of the time (equivalent to $100 \%$ attainment)

\begin{tabular}{|c|c|c|l|}
\hline Case & SRAT air purge & SME air purge & \multicolumn{1}{c|}{ Comments } \\
\hline 1 & 1150 & 225 & Original rad ops design basis \\
\hline 2 & 575 & 225 & SRAT air @ 50\% \\
\hline 3 & 575 & 575 & $\begin{array}{l}\text { SRAT @ } 50 \%, \text { SME at 575 if } \mathrm{H}_{2} \text { evolution in } \\
\text { SME comparable to SRAT }\end{array}$ \\
\hline 4 & 225 & 225 & $\begin{array}{l}\text {-5X reduction in } \mathrm{H}_{2} \text { rate (HNO } \mathrm{H}_{3} \text { flowsheet); } \\
\text { assume SME } \mathrm{H}_{2} \text { comparable to SRAT }\end{array}$ \\
\hline 5 & 115 & 115 & $\begin{array}{l}\text { - 10X reduction in } \mathrm{H}_{2} \text { rate; assume SME } \mathrm{H}_{2} \\
\text { comparable to SRAT }\end{array}$ \\
\hline
\end{tabular}

This space intentionally left blank. 
- Maximum CPC and total emissions are

\section{Annual DWPF $\mathrm{Hg}$ Emissions}

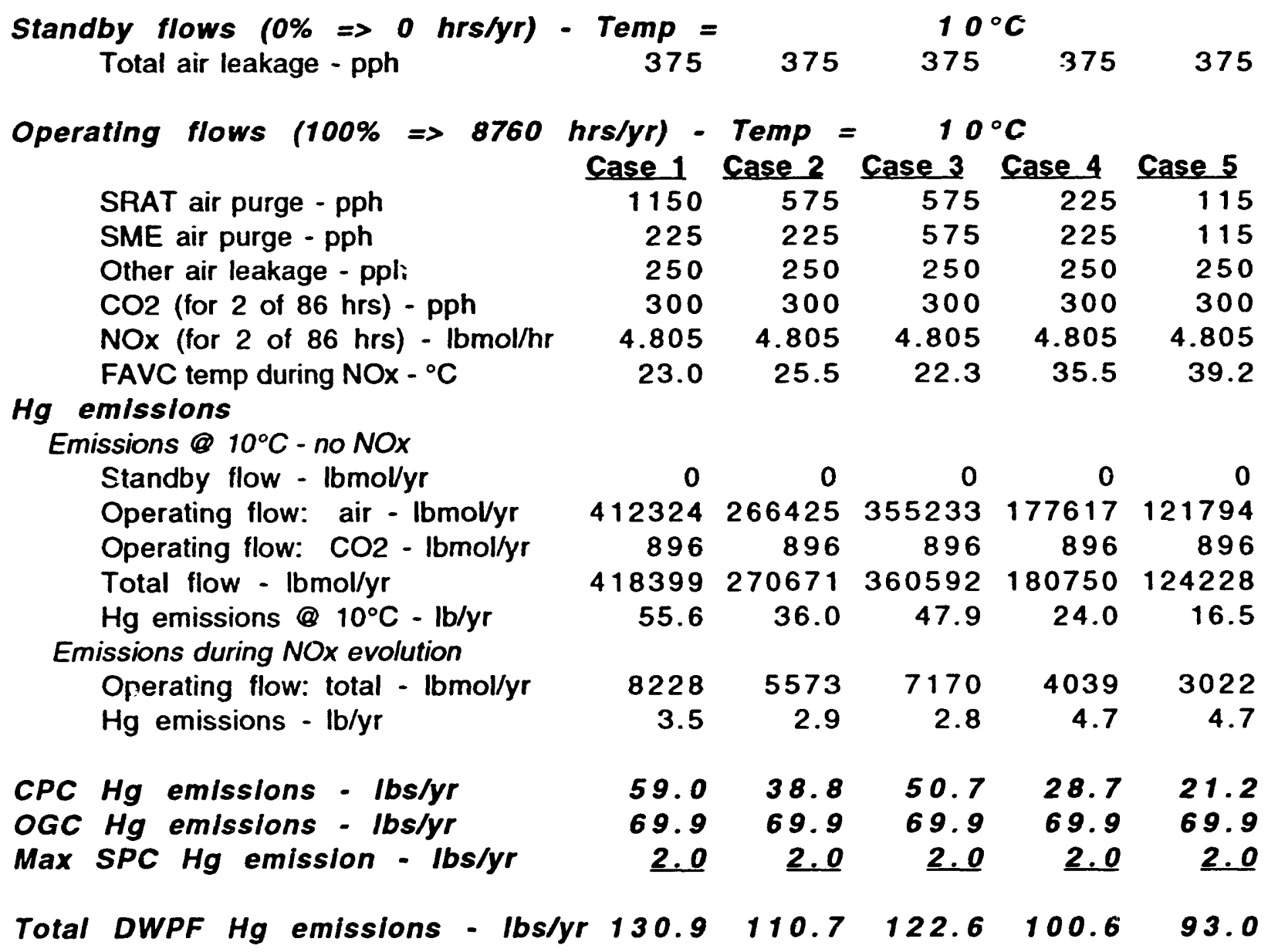

\section{Peak Hg Emissions Rate}

- The peak emissions can be estimated using the peak CPC rate $(4.7 \mathrm{lbs} / \mathrm{hr}$ from Cases 4 and 5 above) for $2 \mathrm{hrs}$ per $100 \mathrm{hr}$ cycle plus the constant rate from the Melter Offgas Systems (69.9 lbs/yr for $8760 \mathrm{hrs} / \mathrm{yr})$.

$$
\begin{aligned}
\text { Peak Hg rate } & =\frac{4.7 \mathrm{lbs} / \mathrm{yr}}{\frac{8769 \mathrm{hrs} / \mathrm{yr}}{100 \mathrm{hrs} / \text { cycle }} * 2 \mathrm{hrs} \text { peak/cycle }}+\frac{69.9 \mathrm{lbs} / \mathrm{hr}}{8760 \mathrm{hrs} / \mathrm{hr}} \\
& =0.035 \mathrm{lbs} / \mathrm{hr}
\end{aligned}
$$




\section{Quallty Assurance}

Spreadsheet calculations were verified by hand calculations. Assumptions, bases, and caclulations were reviewed by L. F. Landon.

\section{References}

1. J. R. Zamecnik, The Effect of Nitric Oxide Oxidation on the DWPF Formic Acid Vent Condenser (FAVC) Exit Temperature - Preliminary Report (U), WSRC-RP-92-1174, to be issued.

2. South Carolina DHEC Air Quality Control Permit, 0080-0066-CA.

3. SRAT Offgas Task Team, Flammability Control Design Criteria for DWPF Radioactive Operation (U), WSRC-RP-91-920, September 13, 1991.

4. Vol. 3, page 206, International Critical Tables, 1933.

5. J. Gmehling, U. Onken, W. Arlt, Vapor-Liquid Equilibrium Data Collection, 1981.

6. A. S. Choi, Preliminary Material Balance Tables for the DWPF Final Wash Flowsheet, WSRC-TR-92-211, June 15, 1992. 

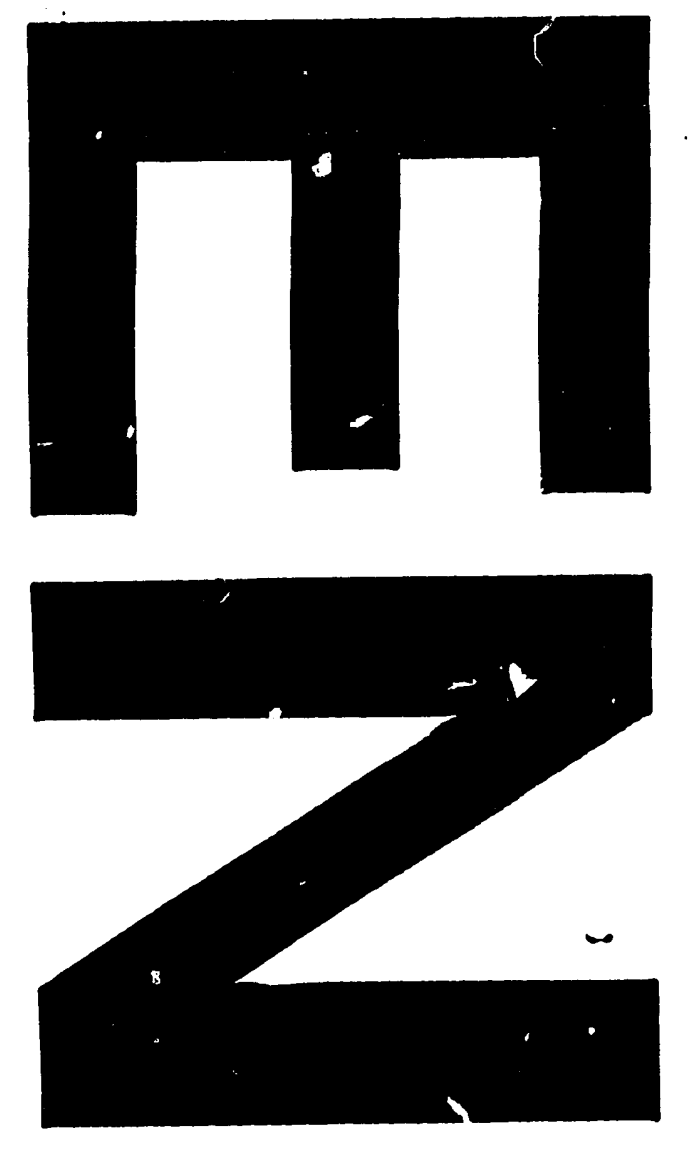

l
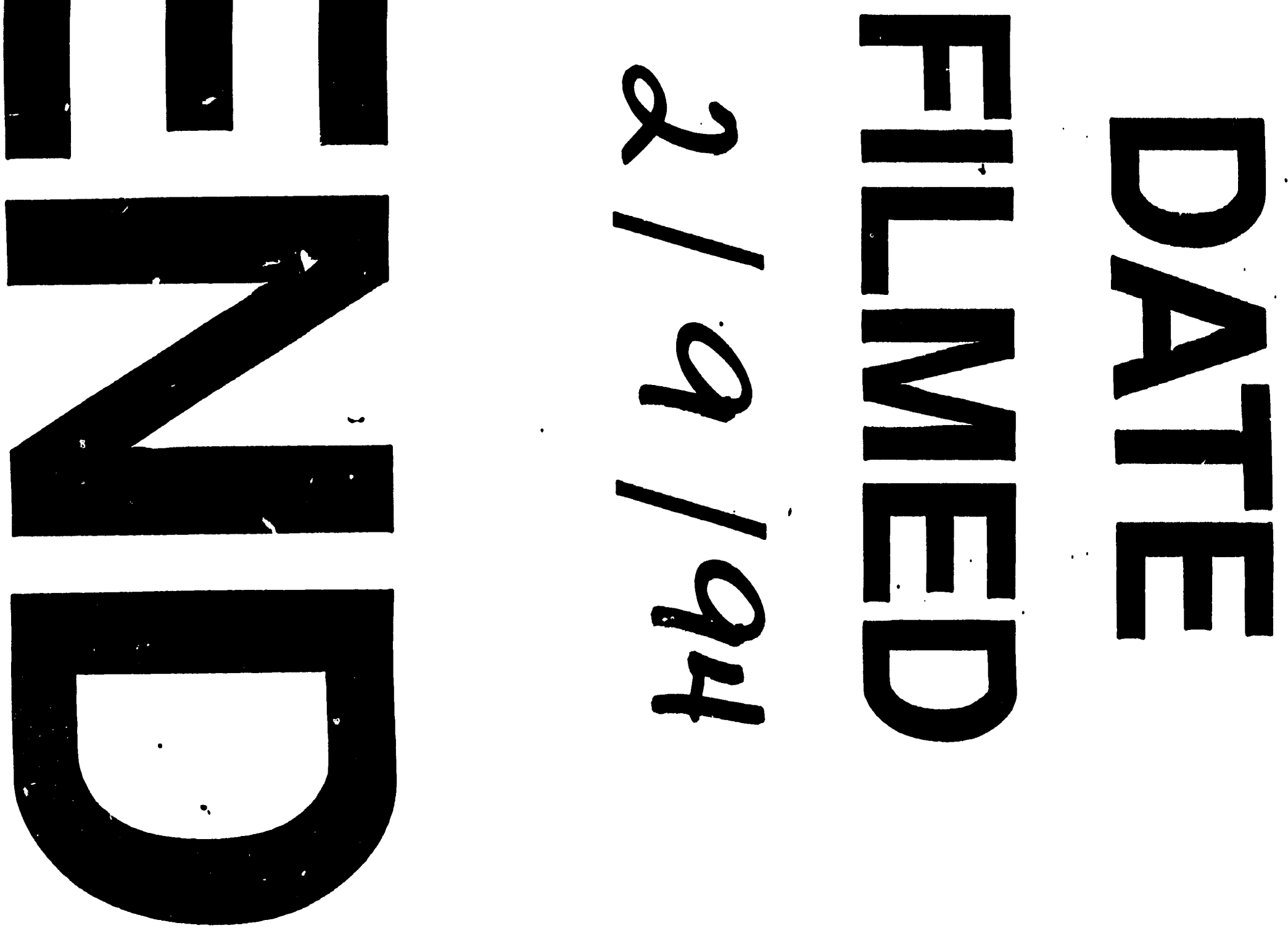